\title{
HOW PRODUCT STRATEGY IN THE MARKETING MIX IS AFFECTING THE GROWTH OF JUA KALI ENTERPRISES IN NORTH IMENTI SUB-COUNTY
}

\author{
${ }^{1}$ Gatobu Jackline Kanana(D), ${ }^{2}$ Paul Gichohi(D) \& ${ }^{3}$ Abel Moguche(D) \\ ${ }^{1}$ Department of Business Administration, Kenya Methodist University \\ Corresponding author's e-mail: gatobujackline@gmail.com
}

How to cite this article: Kanana, J., G., Gichohi, P. \& Moguche, A. (2021). How product strategy in the marketing mix is affecting the growth of Jua Kali enterprises in North Imenti Sub-County. Edith Cowan Journal of Strategic Management, 1(1), 19-26.

\section{ARTICLE INFO}

Article history:

Received Date: $3^{\text {nd }}$ June 2021

Revised Date: $8^{\text {th }}$ June 2021

Accepted Date: $18^{\text {th }}$ June 2021

\section{Keywords:}

Jua kali, product strategy

\section{A B S T R A C T}

Purpose: The purpose of this study was to investigate the effect product strategy on the growth of jua kali Enterprise in North Imenti Sub County, Meru County. The study hypothesized that there is no significant relationship between product and growth of jua kali enterprises.

Design/ Methodology/Approach: The study adopted a descriptive research design. The population comprised of one hundred and twenty eight (128) owner of jua kali enterprises operating within North Imenti Sub County, Meru County and registered by Micro and Small Enterprises Authority Kenya (MSEA-K). A stratified random sampling technique was used to select a sample of ninety seven (97) jua kali enterprises from the total population. Data was collected using a structured questionnaire after which mean and standard deviation were computed while Pearson Correlation, and linear regression done accordingly. Statistical Package for Social Sciences (SPSS) version 22 was used as a statistical tool.

Findings: The results indicated that there is growth in jua kali sector which is contributed by product strategy. The study established that product strategy affects growth of jua kali enterprises hence rejecting the hypothesis. It was therefore concluded that product strategy significantly affects SME's growth.

Contribution to policy and practice: SMEs should invest in their products to ensure they are of desirable quality in order to satisfy their customers and maintain a competitive edge.

Originality/Value: The study is valuable to entrepreneurs seeking better product strategies to grow their enterprises. 


\section{BACKGROUND}

Page 20 of 26

SMEs are key players in the economy and and facilitate inclusive globalization (OECD 2004, IFC, 2010). They have been widely acknowledged as the springboard for sustainable economic development (Osotimehin, Jegede, Akinlabi, \& Olajide, 2012). The term "jua kali" is a Swahili word, which means "hot sun" (Neizert, 1998; Ikoja-Odongo \& Ocholla, 2004). In Kenya, the term jua kali refers to men and women working in the open air, and often under the hot sun and usually classified under the informal sector. According to Bwisa (2017), the jua kali sector in other countries like India is synonymous with one-person establishment. These establishments are usually managed or owned by one person, and accounts for a significant percentage of employment. In the African continent the jua kali sector has been on the forefront of spurring economic development. According to Ofusaa, Duku, Asante and Kojo (2015) the informal sector in Nigeria has acted as the engine of social and economic development in Nigeria. While in the Kenyan context, jua kali enterprises dot several parts of Kenyan towns and mostly are temporary locations (Quinton \& Daniels, 2010). The jua kali sector has been recognized as the back bone of economic growth (Kenya Economic Survey, 2017). According to Njoroge (2015), the challenge facing the small and medium enterprises is need for diversification and creatively improving their products as well as enhancing their marketing techniques to ensure growth.

The Resource Based View theory (RBV) was advanced by Penrose in 1959 avers that superior performance of the organization was determined by how it controlled and made use of its resources. RBV brought into focus the fundamental role played by organizational resources in the competitiveness and performance of the organization in the market (Bridoux, 2004). The RBV theory focuses on the characteristics of organization firm's resources value, rareness, imitability and organization. These features are prominently anchored in product, which ultimately results to competitive advantage in the market (Peteraf \& Barney, 2003). Notably, in the present study, the organizational products are regarded as organizational resources that can be exploited towards creating competitive advantage. The heterogeneity assumption as discussed by Bridoux (2004) is present in the firm's products, hence contributing to the different levels of growth experienced by firms within the same industry. The RBV theory has contributed immensely in understanding the core competencies required for a business firm to gain competitive advantage.

According to Kotler and Armstrong (2014), a product is anything that can be offered to the market for attention, acquisition, consumption to satisfy a certain need thus ensuring that the organization retains its presence or market share in the market. The growth of an enterprise is affected by the ability of the various products to meet the various needs identified or existing in the market (Mirzaei, Micheels, and Boecker, 2016). This study focused on the product design, type and number of products, product features, and technology and innovation as determinants of jua kali enterprises growth.

\section{Research Problem}

According to World Bank (2014) report SMEs in Kenya do not graduate into large enterprises. Some remain small while others die gradually. The failure to survive and grow ultimately leads to jobs losses, marginal income which further threatens economic development and thwarts the realization of vision Kenya's 2030. Majority of the jua kali SMEs in Kenya are faced with challenges of developing quality products, quality packaging that is convenient to the target market, and further fail to vigorously promote their products (Kiveu \& Ofafa, 2014). The 
Kanana, Gichohi \& Moguche (2021)

Page 21 of 26

connection between the product strategy and the growth of SMEs is critical in informing corrective measures. However, there has not been a specific study within the local context that has concentrated on the role of product strategy on the growth of jua kali SME's in Kenya and Meru County in particular. The existing studies by Bowen, Morara and Mureithi (2009), Kipyegon (2009), and Atieno (2001) focused on positioning strategies, financing and other general challenges that SME's face for survival in Kenya. This study therefore aimed at examining the relationship between product strategy and the growth of SMEs and specifically to assess the effects of product strategy and growth of jua Kali enterprises in North Imenti subcounty, Meru County.

\section{MATERIALS AND METHODS}

The study made use of descriptive research design that helped to explore the phenomena in which the relationship among the study variables occurs through correction of primary data. The target population for this study constituted the 128 jua kali enterprises as registered by Micro and Small Enterprises Authority Office in Meru County (MSEA) - Kenya in 2017 and belonging to North Imenti jua kali Association. To establish how product strategy affect growth of Jua kali enterprises, the artisans were asked to quantitatively rate how they select products to sell in their enterprises. The questionnaire was administered to 97 members of Imenti North jua kali association and a total of 61 suitable responses were received. Most of the respondents were female $55.7 \%$ and males at $44.3 \%$ with majority of the respondents $49 \%$ having attained form four qualification. The SME sector that these businesses operated in consisted mainly of agro processors (16.4\%), Leather works (18\%), metal fabricators and welders $(11.5 \%)$, waste recyclers $6.6 \%$ and wood workers (11.5\%). Instrument reliability was established by conducting a pilot survey and computing Cronbach's alpha. The instrument was found to have Cronbach's value of 0.773 which was within the acceptable range of 0.7 to 1.0 and therefore this shows that the instrument was reliable.

\section{RESULTS}

The respondents were presented with a set of seven factors regarding products that they could use to guide their selection of products to sell. They were asked to rate the importance of each factor on a five point scale that ranged from strongly disagree to strongly agree.

Table 1 Importance Ratings of Product Factors

\begin{tabular}{|c|c|c|c|c|c|c|}
\hline Statement $(\mathrm{N}=\mathbf{6 1})$ & 1 & 2 & 3 & 4 & 5 & Mean \\
\hline $\begin{array}{l}\text { Is spend in enhancing the design of } \\
\text { my products }\end{array}$ & $1(1.6 \%)$ & $5(8.2 \%)$ & $24(39.3 \%)$ & $21(34.4 \%)$ & $10(16.4 \%)$ & 3.56 \\
\hline $\begin{array}{l}\text { Our products are competitive in the } \\
\text { market due to their aesthetics, } \\
\text { design and utility }\end{array}$ & $0(0.0 \%)$ & $4(6.6 \%)$ & $15(24.6 \%)$ & $33(54.1 \%)$ & $9(14.8 \%)$ & 3.77 \\
\hline $\begin{array}{l}\text { The enterprise has continued to } \\
\text { embrace emerging technologies }\end{array}$ & $0(0.0 \%)$ & $5(8.2 \%)$ & $9(14.8 \%)$ & $22(36.1 \%)$ & $25(41.0 \%)$ & 4.10 \\
\hline $\begin{array}{l}\text { The type and number of products } \\
\text { developed determines my } \\
\text { profitability }\end{array}$ & $0(0.0 \%)$ & $3(4.9 \%)$ & $11(18.0 \%)$ & $32(52.5 \%)$ & $15(24.6 \%)$ & 3.97 \\
\hline $\begin{array}{l}\text { There are product designers within } \\
\text { my business contributing to }\end{array}$ & $0(0.0 \%)$ & $3(4.9 \%)$ & $11(18.0 \%)$ & $28(45.9 \%)$ & $19(31.1 \%)$ & 4.03 \\
\hline
\end{tabular}


Kanana, Gichohi \& Moguche (2021)

Page 22 of 26

enhanced product features

There is continuous product $0(0.0 \%) \quad 1(1.6 \%) \quad 15(24.6 \%) \quad 28(45.9 \%) \quad 17(27.9 \%) \quad 4.00$

innovation

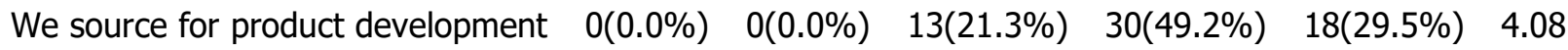
and designs from other people and organizations

As shown in Table $125(41.0 \%)$ respondents strongly agreed that their enterprises have continued to embrace emerging technologies, as reflected with the average mean of 4.10 . Further analysis revealed that $21(34.4 \%)$ respondents agreed that they spent in enhancing the design of their products as was evidenced in the average mean of 3.56. In like manner $33(54.1 \%)$ respondents agreed that their products are competitive in the market as signified with the average mean of 3.77. In addition, 32(52.5\%) residents agreed that the type and number of developed products determines their profitability reflecting an average mean of 3.97. Likewise, $28(45.9 \%)$ respondents also agreed that there are product designers contributing to enhance product features as evidenced in the average mean of 4.03 . On product innovation, $28(45.9 \%)$ respondents agreed that there is continuous product innovation achieving an average mean of 4.00 and $30(49.2 \%)$ respondents agreed to sourcing product development and designs from other people and organizations as evidenced with average mean 4.08.

\section{Regression Analysis}

Table 2 Model Summary

\begin{tabular}{|c|c|c|c|c|c|}
\hline $\mathbf{R}$ & R Square & $\begin{array}{l}\text { Adjusted } \\
\text { Square }\end{array}$ & $\mathbf{R}$ & Std. Error of the Estimate & Durbin-Watson \\
\hline 0.553 & 0.306 & 0.294 & & 2.60655 & 1.708 \\
\hline
\end{tabular}

Predictors: (Constant), Product strategy

Dependent Variable: Growth of jua kali SMES

Model summary in Table 2 shows strong positive correlation between product strategy and growth of jua kali SMEs. The coefficient of determination (R Square) shows that variations in product strategy account for 30.6 percent of the variations in growth of jua kali SMEs. Variables not included in this model account for remaining 69.4 percent of the variations. Durbin-Watson statistic further shows no auto-correlation among the residual errors ( $d=1.708$, approximately near two). Table 3 shows the analysis of variance results.

Table 3 ANOVA Results

\begin{tabular}{|c|c|c|c|c|c|c|c|}
\hline Model & & $\begin{array}{l}\text { Sum } \\
\text { Squares }\end{array}$ & of & df & Mean Square & $\mathbf{F}$ & Sig. \\
\hline \multirow[t]{2}{*}{1} & Regression & 164.992 & & 1 & 164.992 & 24.285 & 0.000 \\
\hline & Residual & 373.675 & & 55 & 6.794 & & \\
\hline
\end{tabular}


Table 3 shows results for analysis of variance tested using F-statistics, which tests the null hypothesis that growth of SMEs is non-linear to product strategy. The results show that the $p$ value corresponding to the observed F-statistics is 0.000 , which is less than 5 percent $(F(1,55)$ $=24.285, p=0.000<0.05)$. Therefore, the study rejects the null hypothesis hence concluding that product strategy has significant linear relationship to growth of jua kali SMEs.

Table 4 Regression Results

\begin{tabular}{lccccc}
\hline \hline & & B & Std. Error & t & Sig. \\
\hline (Constant) & 8.806 & 3.843 & & 2.292 & 0.026 \\
Product strategy & 0.681 & 0.138 & 0.553 & 4.928 & 0.000 \\
\hline
\end{tabular}

As shown in Table 4 the p-value corresponding to product strategy is 0.000 , which less than 5 percent. The study set out to investigate the relationship between product strategy and growth of jua kali SMEs. The study had a null hypothesis that, there is no significant relationship between product strategy and growth of jua kali SMEs at 5 percent significance level. The regression equation of the linear regression analysis is as shown in equation (I).

$$
r=8.806+0.681 X_{1}+e
$$

Where

Y - Dependent variable (Growth of SMEs)

$\mathrm{X}_{1}$ - Product Strategy

e - Regression error term

Therefore, the study rejects the null hypothesis implying that growth of SMEs relates positively and significantly to product strategy. This results coincides with that of (Janet \& Ngugi, 2014) that product development strategy was the key critical factor of entrepreneurial marketing that influences growth of SMEs.

\section{DISCUSSION}

The study revealed a positive relationship between product strategy and SME's growth $(r=0.553)$. The coefficient of determination ( $R$ Square) shows that variations in product strategy account for 0.306 of the variations in growth of jua kali SMEs. Variables not included in this model account for remaining 69.4 percent of the variations. Results for analysis of variance tested using F-statistics, which tests the null hypothesis that growth of SMEs is non-linear to product strategy showed that the $\mathrm{p}$-value corresponding to the observed F-statistics is 0.000 , which is less than 5 percent $(F(1,55)=24.285, P=0.000<0.05)$. Therefore, the study rejects the null hypothesis hence concluding that product strategy has significant linear relationship to growth of jua kali SMEs.

The unstandardized beta coefficient (beta $=0.681, p=0.00$ ) further emphasizes the existence of a strong positive relationship indicating that; as the product strategies changes by one unit, $68.1 \%$ SME growth is realized. The p-value corresponding to distribution strategy is 0.000 , which less than 5 percent. Therefore, the study rejects the null hypothesis implying that growth of SMEs relates positively and significantly to product strategy. The first finding this study is 
Kanana, Gichohi \& Moguche (2021)

Page 24 of 26

consistent with that of Jones (2010) who found that pricing strategy and new product development strategy are the major influences of entrepreneurial marketing that affects the growth of SMEs. The Kenyan government through the ministry of trade industry has endeavored to support $S M E, S$ and jua kali through a number of ways including sourcing for market for the products, access to credit, youth and women access to funds such as UWEZO through AGPO and enhancement of technical institute to deepen the skill (Ministry of industry, trade and cooperatives, 2018).

\section{CONCLUSION}

This study sought to assess the effect of product strategy on the growth of jua kali enterprises in North Imenti Sub County of Meru County. The study concluded that product strategy significantly affects SME's growth $(R=0.553$, Beta $=0.68, F=24.85, P=0.00<0.05)$. Therefore, the study rejected the null hypothesis hence concluding that product strategy has significant linear relationship to growth of jua kali SMEs. Marginal implementation of product strategy led to $68 \%$ growth of jua kali enterprises in North Imenti while holding other factors constant. The study therefore established that product strategy affect growth of jua kali enterprises in Meru County.

\section{Areas for Further Research and recommendations}

The study therefore recommends the owner entrepreneur managers to employ product development as a strategy for growth of the jua kali enterprise. The study recommends that; SMEs should invest in their products to ensure they are of desirable quality in order to satisfy their customers and maintain a competitive edge.

\section{REFERENCES}

Atieno, R. (2001). Formal and Informal institutions Lending policies and access to credit by small scale enterprises in Kenya. African Economic Research Consortium, 1 (6), 123-154. Retrieved from https://ideas.repec.org/s/aer/rpaper.html

Bridoux, F. (2004). A resource-based approach to performance and competition: an

Overview of the connections between resources and competition. Luvain, Belgium Institutet de Gestion, UniversiteCatholique de Louvain, 2(1), 1-21. Retrieved fromhttp://www.uclouvain.be/cps/ucl/doc/iag/documents/WP 110 Bridoux.

Bwisa, H. (2017, April 13). Jua Kali sector is big business; ignore it at your own peril. Standard Newspaper Kenya. Retrieved from https://www.standardmedia.co.ke/article/2001236124/jua-kali-sector-is-biq-businessignore-it-at-your-own-peril

Casson, R. J., \& Farmer, L. D. (2014). Understanding and checking the assumptions of linear regression: a primer for medical researchers. Clinical and Experimental Ophthalmology, 42, 590-596. doi:10.1111/ceo.12358

Das, K. R., \& Imon, R. A. (2016). A Brief Review of Tests for Normality. American Journal of Theoretical and Applied Statistics, 5(1), 5-12. doi:10.11648/j.ajtas.20160501.12

Daoud, J. I. (2017). Multicollinearity and regression analysis. Journal of Physics: Conference Series, 949(1), 012009. doi:10.1088/1742-6596/949/1/012009 
Ernst, A. F., \& Albers, C. J. (2017). Regression assumptions in clinicalpsychology research practice-asystematic review of commonmisconceptions. Peer Casper J Albers, 5, e3323. doi:10.7717/peerj.3323

Ferreira, J., Azevedo, G.,\& Ortiz, F. (2011). Contribution of Resource - Based View and Entrepreneurial Orientation on Small Firm Growth. Cuadernos de Gestión, 11(1), 95 116.doi: $10.5295 /$ cdg.100185jf

Janet, M., \&Ngugi, K. (2014). Influence of Entrepreneurial Marketing on the Growth of SMES in Kiambu Town-CBD, Kenya. European Journal of Business Management, 1(11), 361-377. Retrieved from https://www.iprjb.org/journals/index.php/IJEPM/article/view

Kenneth, S., Anderson, \& Eddy, G.(2011). Creating SCA: RBV analysis of Ganzaga University Basket BallProgramme. Journal of sport administration and supervision, 3 (1), 10-21. Retrieved from https://quod.lib.umich.edu/cgi/p/pod/dod-idx/creating-a-sustainablecompetitive-advantage-a-resource.pdf

Kipchumba, L. (2015). Effects of credit assessment on loan repayments in MFI's in Nakuru Central Business District (Unpublished MBA Thesis), Kabarak University. Nairobi. Retrieved fromhttp://kabarak.ac.ke/

Kipyegon, B. (2009). Positioning Strategies Adopted by Firms that offer Courier services in Kenya (Unpublished Thesis) School of Business, and University of Nairobi. Retrieved from http://erepository.uonbi.ac.ke:8080/xmlui/handle/123456789/13602

Kiveu, M., \&Ofafa, G. (2013). Enhancing market access in Kenyan SMEs using ICT. Global Business and Economics Research Journal, 2(9), 29-46. Retrieved from http://www.journal.globejournal.org

Klein, A. G., Gerhard, C., Büchner, R. D., Diestel, S., \& Schermelleh-Engel, K. (2016). The detection of heteroscedasticity inregression models for psychological data. Psychological Test and Assessment Modeling, 58(4), 567-592. Retrieved from https://www.psychologie-aktuell.com/fileadmin/download/ptam/42016_20161219/01_Klein-final.pdf

Mang'unyi, E., Mwanzia, C., \& K. Govender, K. (2018). Employment creation in Kenya: Exploring the Jua Kali enterprises. Problems and Perspectives in Management, 16, 453-467. https://doi.org/10.21511/ppm.16 (4).2018.38

Ministry of industry, trade and cooperatives. (2018). Development of Small \& Medium Enterprises and the Jua Kali Sectorâ $\square$ Ministry of Industry, Trade and Cooperatives. Retrieved July 20, 2019, from https://www.industrialization.go.ke/index.php/milestones/480-development-of-smallmedium-enterprises-and-the-jua-kali-sector 
Kanana, Gichohi \& Moguche (2021)

Page 26 of 26

Ngugi, T. (2015).Influence of Kenya Industrial Estate services on the growth of Jua Kali enterprises in Meru County, Kenya (Unpublished Master Thesis), University of Nairobi, Kenya. Retrieved from http://hdl.handle.net/11295/92885

OECD (2017). Enhancing the contributions of SMEs in a Global and Digitalized Economy, Paris KNBS (2016), Micro, Small \& Medium Establishments: Basic Report, Nairobi. Retrieved from https://www.oecd.org/mcm/documents/C-MIN-2017-8-EN.

Ofusaa, B., Duku, M., Asante, R. \&Kojo, P. (2015). Role of small and medium scale enterprises in the economic development of Ghana. (Unpublished Master Thesis). Kwame Nkrumah University, Kumasi, Ghana. Retrieved from http://hdl.handle.net/123456789/2537

Ole Kulet, J. L., Wanyoike, D. M., \& Koima, J. K. (2019). Effects of best product strategic positioning on organizational performance in telecommunication industry, in Kenya. The Strategic Journal of Business \& Change Management, 6 (1), 387 - 400.

Osborne , J. W. (2013). Normality of residuals is a continuous variable, and does seem to influence the trustworthiness of confidence intervals: A response to, and appreciation of, Williams, Grajales, and Kurkiewicz (2013). Practical Assessment, Research \& Evaluation, 18(12), 1-9. Retrieved from https://pareonline.net/getvn.asp?v=18\&n=12

Penrose, E. T. (2009). The theory of the growth of the firm. Oxford: Oxford University Press.

Peteraf, M. A., \& Barney, J. B. (2003). Unravelling the resource-based tangle. Managerial and decision economics, 24(4), 309-323. doi: 10.1002/mde.1126

Razali, N. M. (2011). Power comparisons of Shapiro-Wilk, Kolmogorov-Smirnov, Lilliefors and Anderson-Darling tests. Journal of Statistical Modeling and Analytics, 2(1), 21-33. Retrieved from https://www.nrc.gov/docs/ML1714/ML17143A100.pdf

Rigby, D., \&Rogers, P. (2000).Winning in Turbulence - Strategies for Success in Turbulent Times. European Business Journal, 12 (2), 76-86. Retrieved from www.ssrn.com 